\title{
EARLY CHINESE MANUSCRIPT WRITINGS FOR THE NAME OF THE SAGE EMPEROR SHUN 舜, AND THE LEGACY OF WARRING STATES-PERIOD ORTHOGRAPHIC VARIATION IN EARLY CHINESE RECEIVED TEXTS
}

\author{
Adam D. Smith*
}

\begin{abstract}
The graph used to write the name of the mythical emperor Shun 舜 in received texts is a puzzling one. It is not obvious that any component in the graph, as it appears today, is semantically motivated, nor is there any element well suited to representing the name Shun phonetically. Texts like the Shuowen jiezi 說文解字 preserve an alternate writing of the name under the rubric "guwen 古文," but this too is hard to analyze in terms of the semantic and phonological motivation of the graph components. Without a clear understanding of why the name Shun is written the way it is, a reliable reconstruction of its Old Chinese pronunciation is difficult, and many of the graphic and phonological associations with "Shun" and related words made by early Chinese script, texts, and commentaries would be opaque.

A graph that is clearly writing the name Shun, seen for the first time in two of the Warring States-period manuscripts from Guodian 郭店, partially resolved these difficulties, and in particular the question of the phonological spelling of the name. This in turn allows a series of interesting textual problems to be resolved. This article presents a selection of these, and discusses their implications for the history of the Chinese script and for textual transmission.
\end{abstract}

This article takes as its starting point a graph used to write the name of the "Sage Emperor" Shun 舜 that is encountered in several Warring States manuscripts that have come to light in recent decades, including the “Qiong da yi shi” 窮達以時 and “Tang Yu zhi dao" 唐虞之道

*Adam D. Smith 亞當, University of Pennsylvania; email: adsmit@sas.upenn.edu.

My thanks to Wolfgang Behr, Crispin Williams, Sarah Allan, and Huang Guohui 黄國輝 for insightful comments and corrections to the first draft of this article.

(c) The Society for the Study of Early China and Cambridge University Press 2017 
manuscripts from Guodian 郭店. ${ }^{1}$ Although its linguistic value is easily identified by the contexts in which it occurs, this manuscript graph for "Shun" requires a careful palaeographic and phonological analysis in order to explain the form in which it appears. This in turn allows us to re-read and make sense of several otherwise baffling passages in received texts. Examples are drawn from Zheng Xuan's 鄭玄 (127-200 C.E.) commentary to the Zhongyong 中庸 and the Gongyang 公羊 commentary to the Chunqiu 春秋.

\section{Methodological Preliminaries}

The Old Chinese (OC) phonological apparatus employed here is the most recent system of reconstruction provided by Baxter and Sagart. ${ }^{2}$ I assume, in particular, that the rhymes of OC syllables develop as described by Baxter and Sagart. I also assume their treatment of lateral initials $\left({ }^{*} 1-\right.$, * 1 - and complex onsets involving them). Some individual words are reconstructed here differently from the way in which Baxter and Sagart handle them, and will be identified as they occur, but these individual departures will still be made within the range of possibilities that their system permits. Some words treated in this article are reconstructed by Baxter and Sagart with coda *-r (or *-[r], or *-[n]), which is used in their system to account for contacts between forms that would otherwise be reconstructed with ${ }^{*}$-j and ${ }^{*}$-n. I am agnostic about the correctness of this approach, and since the arguments presented here are compatible with the relevant words being *-n, I adopt * $n$ in all cases. I am also agnostic about their pharyngealization proposal for the type-A vs. type-B (non-division III vs. division III) distinction. ${ }^{3}$ Since the nature of that distinction does not play a deep role in the arguments here, the superscript ${ }_{-}^{*}$ can be considered a notation for the distinction, rather than a commitment to a specific phonological value. Middle Chinese (MC) values are given according to the Guangyun 廣韻 unless otherwise stated, and in Baxter's MC transcription. ${ }^{4}$ Asterisks mark OC forms, but

1. Jingmenshi Bowuguan 荊門市博物館, Guodian Chu mu zhujian 郭店楚墓竹簡 (Beijing: Wenwu, 1998); Scott Bradley Cook, The Bamboo Texts of Guodian : A Study \& Complete Translation (Ithaca: East Asia Program, Cornell University, 2012).

2. William Hubbard Baxter and Laurent Sagart, Old Chinese: A New Reconstruction (Oxford University Press, 2014); William Hubbard Baxter and Laurent Sagart, "Baxter-Sagart Old Chinese Reconstruction, Version 1.1," 2014, http:/ / ocbaxtersagart.lsait. lsa.umich.edu/BaxterSagartOCbyMandarinMC2014-09-20.pdf.

3. Baxter and Sagart, Old Chinese, 68-76.

4. Yu Naiyong 余廼永, Xinjiao huzhu Song ben Guangyun 新校互註宋本廣韻 (Shanghai Cishu, 200o); William Hubbard Baxter, A Handbook of Old Chinese Phonology (Berlin: Mouton de Gruyter, 1992) ch. 2. 
are not used for MC. MC and Modern Standard Chinese forms are italicized.

The concept of a "xiesheng 諧聲 series" has had a useful life, but for various reasons I think it needs to be retired. It refers to a set of graphs when what we should be referring to is a set of pairings of phonological forms with written forms. I will refer to these parings as "(phonological) spellings" when their use is phonologically motivated. A phonological spelling can involve either a subcomponent of a graph (sheng pang 聲旁, “phonophoric," etc.) or the entire graph (jiajie 假借, "phonetic loans," etc.). "Xiesheng series" also fails to convey adequately the richly informative historical complexity and active nature of spellings, which can vary over time, by region, and by scribe or text genre (examples of which we will see below).

Methodologically, I assume that OC spellings should be "regular" at the time of their creation. ${ }^{5}$ We will call the spelling for a word regular when the rhyme (not including tone category) and place of articulation of the main initial are identical to other words with the same regular spelling (with nasal vs. orals, and stops vs. affricates vs. fricatives, considered distinct); pre-initials, type-A vs. type-B, voicing and aspiration of the main initial, and tone category are all free to vary. "Identical" means identical at the time of use (hence, although we will assume methodologically that all spellings should initially be regular, conservatively retained spellings can be expected to become irregular due to sound changes affecting words sharing the same spelling). The original motivation behind this complicated spelling rule appears to have included the principle that spellings ignore features of the syllable potentially affected by morphological processes (least controversially, post-codas and initial voicing; more controversially, initial consonant clusters, affixes, etc.).

Any spellings that appear to be irregular will be identified, and the duty to account for them shouldered (if not always adequately discharged). There are several reasons why we encounter what appear to be irregular spellings: the pairing may not in fact be a phonological spelling at all; a previously regular conservative spelling may have become irregular due to sound change; the spelling would be regular if we had a better model of OC phonology (including a better model for

5. This, broadly speaking, is the approach of Baxter and Sagart, Old Chinese, 26-32, who aim to recover a good deal of complexity from spelling patterns in the script. Schuessler is more reluctant to add complexity to OC reconstruction inspired by otherwise difficult-to-explain spellings (Axel Schuessler, Minimal Old Chinese and Later Han Chinese : A Companion to Grammata Serica Recensa [Honolulu: University of Hawai'i Press, 2009]). 
regular spelling); the spelling is regular, but only in a dialect that we are not modelling adequately; scribes adopted an irregular spelling because no regular one was available, or for some other pragmatic reason. Distinguishing between these alternatives on empirical grounds is one of the areas in which an integration of research in OC phonology with palaeography holds considerable promise.

I also assume what I consider to be an uncontroversial consensus on the evolution of script varieties in the late centuries B.C.E., which I summarize briefly here. ${ }^{6}$ Prior to the Qin conquest of the other Warring States, distinct traditions of scribal practice at the major centers of population had led to regional innovations and divergence in the script. These divergences were often structural, rather than merely cosmetic, extending to differing choices of phonological spellings and other choices of components for individual graphs. Measures carried out by the Qin Empire (221-206 B.C.E.) were very successful in eliminating the previously innovating orthographic traditions of the former eastern states and replacing them with Qin orthographic standards throughout the empire. 7 The Western Han inherited the unified Qin scribal standards largely intact (although innovations within the unified script continued to accrue over the Han period [206 B.C.E.-220 C.E.]). When Han observers encountered fourth or third century B.C.E. textual materials in the obsolete orthography of the former eastern states, they referred to them as guwen 古文 "old writing." Most descriptions of these guwen discoveries in Western Han (206 B.C.E.-9 C.E.) sources are compatible with their identification as relatively recent productions in an obsolete script. During the Eastern Han (25-220 C.E.), however, a belief developed among some authors that the script of the guwen discoveries was a pristine and semantically transparent script of remote antiquity, deliberately employed by Kongzi 孔子 and other editors to transcribe prestigious ancient texts, rather than a relatively recently discontinued set of regional variants. This mistaken belief was shared by the Song-period compilers of guwen script collections like the Hanjian 汗簡 (late tenth century) and

6. The consensus that follows is essentially that found in Qiu Xigui, Chinese Writing, trans. Gilbert Mattos and Jerry Norman (Berkeley: Society for the Study of Early China and the Institute of East Asian Studies, University of California, 2000).

7. On this point, the consensus is preferable to the alternative offered by Imre Galambos, "The Myth of the Qin Unification of Writing in Han Sources," Acta Orientalia Academiae Scientiarum Hungaricae 57.2 (2004): 181-203. Although much of Galambos' discussion is compelling, his conclusions are misleading when distilled into the claim implied by his title. Excavated and received evidence are in complete agreement about the reality and nature of the Qin script unification: its main effect was a massive cull of orthographic variation from the eastern states. 
its rearrangement on phonological principles, the Guwen sisheng yun 古文四聲韻 (1044 C.E.). ${ }^{8}$ It remained a frequently articulated belief until the twentieth century.

One persisting consequence of the Qin elimination of competing script varieties, and the Han and later inheritance of the Qin script standard, is the relative ease with which we today, as inheritors of the Qin standard, read texts produced during the Qin or Western Han, compared with the greater orthographic challenges of Chu manuscripts from the same regions only a century or two earlier. Occasionally, in a received text, a puzzling graph or expression that has presented a challenge to later interpreters has a ready analysis when reconsidered in the light of guwen script forms. We will see some examples in this article.

\section{Writing "Shun"}

The example of the writing for the name of the Sage Emperor "Shun" is a valuable one because it is exactly the kind of culturally elevated, supposedly ancient vocabulary item for which one might expect a scribal curriculum to have preserved a stable conception of how it ought to have been written. Instead we find the opposite: a variety of written forms during the Eastern Zhou, the product in part of semantically and phonetically unmotivated graphic reanalysis, followed by fixation of just one of the opaque outcomes through the Han-period stabilization. 9 At the same time, although our account of this particular graph is not entirely complete, we nevertheless find that with a modern knowledge of palaeography and phonology, we understand the writing of this sage king's name and the changes it underwent much better than the fourth-century scribes who actually produced our exemplars, or the Han scholars who in their encounters with guwen were struggling with similar palaeographic challenges to our own.

8. Huang Xiquan 黄錫全, Hanjian zhushi 汗簡注釋 (Wuhan Daxue, 1990); Li Ling 李 零 and Liu Xinguang 劉新光, Hanjian, Guwen sisheng yun 汗簡, 古文四聲韻 (Beijing: Zhonghua, 1983).

9. By "motivated" changes, I mean innovations like changes in phonetic spellings, or the addition or substitution of semantic components, or a structural simplification, for which a rationale could probably be elicited from a thoughtful script user. "Unmotivated" changes are those for which script users are less able to identify a function. For a preliminary exploration of "motivation" in this sense, see Adam Daniel Smith, "Are Writing Systems Intelligently Designed?" in Agency in Ancient Writing, ed. Joshua Englehardt (Boulder: University Press of Colorado, 2013), 77-93. 


\section{Contextual Identification in the Guodian Manuscripts}

A Warring States-period non-Qin writing for "Shun," so different from the received form as to be unrecognizable, was first clearly exemplified by several instances in two texts among the manuscripts from Guodian, "Qiong da yi shi" and "Tang Yu zhi dao." On strips 2 and 3 of "Qiong da yi shi," we encounter, at the beginning of a list of summary anecdotes of distinguished persons of antiquity, a passage that reads:

X耕於歷山, 陶拍於河游。立而為天子, 遇堯也。10

X tilled the soil on Li Mountain, and made pottery on the banks of the river. That he should have been established as ruler, the Son of Heaven, was thanks to his encounter with Yao 堯. ${ }^{11}$

The narrative context is so specific that the identification of the first word as the name of Yao's successor, Shun, could be made with confidence no matter what graphic shape appeared in that slot in the text, and without reference to any scheme for Old Chinese phonology. Additional occurrences from Guodian confirm the identification, as do further exemplars among the looted manuscripts purchased on the antiquities market and now in the Shanghai Museum and Tsinghua University. Because the context was so decisive in this case, the first publication of the Guodian texts made no mention of the form of the graph, which differs markedly from the received orthography. ${ }^{12}$

10. Unless there is a special reason to do otherwise, passages from texts in non-standard orthographies will be "normalized," that is, written as a linguistically identical passage might appear in a received text. Issues of palaeographic interpretation that are not immediately relevant will simply be elided. Unless otherwise noted, translations are my own.

11. Jingmenshi Bowuguan, Guodian Chu mu zhujian, 27, 145; Cook, The Bamboo Texts of Guodian, 454, 458.

12. Subsequent, more detailed discussions of the graph form, to which this study is indebted, include Wei Yihui 魏宜輝, “Shixi Chujian wenzi zhong de 'yi' yu 'Shun' zi 試析楚簡文字中的“疑'與'舜'字," in Xin chutu wenxian yu gudai wenming yanjiu 新出土 文獻與古代文明研究, ed. Xie Weiyang 謝維揚 and Zhu Yuanqing 朱淵清 (Shanghai Daxue, 2004), 157-61; Chen Sipeng 陳斯鵬, “Guodian Chujian jiedu si ze 郭店楚簡解 讀四則," in Guwenzi yanjiu di ershisi ji 古文字研究第二十四輯, ed. Zhongguo Guwenzi Yanjiuhui 中國古文字研究會 and Zhongshan Daxue Guwenzi Yanjiusuo 中山大學古 文字研究所 (Beijing: Zhonghua, 2002), 409-12; Ji Xusheng 季旭昇, “Du Guodian, Shangbo jian wu ti: Shun, he hu, shen er yi, qiang you ci, wan qiu 讀郭店、上博簡五 題: 舜、河汻、紳而易、牆有茨、宛丘, " in Zhongguo wenzi xin nianqi qi 中國文字新廿 七期, ed. Zhongguo Wenzi Bianji Weiyuanhui 中國文字編輯委員會 (Taibei: Yiwen, 2001), 113-20. 


\section{The Variety of Forms for Writing "Shun"}

Before palaeographic exemplars became available at the end of the twentieth century, there was no satisfactory explanation for the form of any of the writings for "Shun" preserved in received texts. Neither the Han commentators nor Qing philologists understood where the graphs had come from. ${ }^{13}$

Before addressing the diversity of early forms, let us begin by looking at the current state of the graph and how it results from relatively recent developments. The aim here is to illustrate and reinforce some concepts and terminology that will be useful subsequently. The form of the graph in the contemporary script standard could be thought of as consisting of " $"$, and 舛. The last of the three, in origin a pair of mirror-image inverted copies of the "foot" pictogram, 止, is the only one that has been stable over a long period of time. The component 舛 is shared, e.g., with 舞, for wu "dance," in which it has a clear semantic motivation. The remainder is the result of relatively recent unmotivated change. Pre-modern print editions often maintain a conservative distinction between the top components of 舜 and 受 (Figure ${ }^{14}$ ).

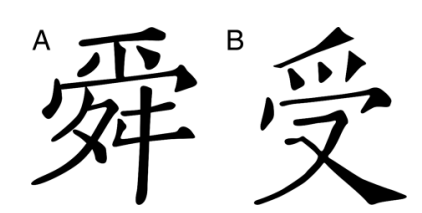

Figure 1. Graph examplars for 舜 and 受.

Graphic changes on this pattern, in which a rare or hard-to-analyze graphic component is replaced, without semantic or phonological motivation, by a visually similar and more frequently occurring component, are common across the history of the script. The usual Chinese term for this is ebian 訛變 "erroneous change," but I propose the term "attraction," to capture more specifically the way in which the less easily recognized visual form is "dragged" into aligment with a more commonly occurring pattern.

13. See, e.g., the entry for shun 舜 in Duan Yucai 段玉裁 (1735-1815 C.E.), Shuowen jiezi zhu 說文解字注 (Shanghai Guji, 1988), 234.

14. 1704 edition of the Guang yun in the collection of Waseda University library, call number: 0401757 (http:/ / www.wul.waseda.ac.jp/kotenseki/, accessed June 13, 2017). 


\section{Xiaozhuan 小管 and guwen Forms in Received Sources}

We get more insight into the diversity of writings for "Shun" by examining dictionaries that aimed deliberately at the preservation of pre-Qin graph forms, of which the Shuowen jiezi 說文解字 is the earliest to have survived, and the best known. ${ }^{15}$ The Hanjian 汗簡 gathers together, in an order based on the Shuowen, all guwen exemplars known to its compiler, Guo Zhongshu 郭忠恕 (d. 977 C.E.). Its rearrangement into phonological order by Xia Song 夏竦 (985-1051 C.E.), as the Guwen sisheng yun 古文四 聲韻, provides an alternative view of the same data. ${ }^{16}$ Figure 2 shows forms for 舜 as preserved in several transmitted sources of this type.
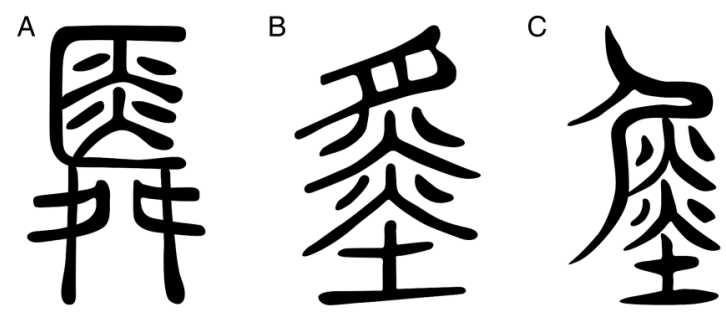

Figure 2. A. Shuowen xiaozhuan, B. Shuowen guwen, and C. Hanjian guwen forms of 舜.

The component 舛 is clearly present in form A, the headword for the entry for 舜 in the Shuowen in xiaozhuan, the canonical script standard for the Qin and Han periods. The motivation for the top half of the xiaozhuan form $A$ is obscure, but presumably the received form with which we are more familiar derives from it. Forms $B$ and $C$ are each identified as guwen in their respective sources. This is an indication that they derive from the Warring States-period eastern-state manuscript texts that are known to have come to light and attracted philological interest during the Han period, although as mentioned above an additional layer of more "fantastic" significance had been applied to guwen forms by the compilers of the Shuowen and the Hanjian.

The two guwen forms are essentially unrecognizable as relatives of the received orthography 舜 or its xiaozhuan precursor. Various possible structural components suggest themselves: 夕 or 肉, 炎, 土, and 尸. None of these is obviously motivated in a writing for Shun, or any of the other

15. Xu Shen 許慎 (c. 55-C. 149 C.E.), Shuowen jiezi 説文解字, ed. Xu Xuan 徐鉉 (916991 C.E.) (Beijing: Zhonghua, 1998).

16. Li Ling and Liu Xinguang, Hanjian, Guwen sisheng yun; Huang Xiquan, Hanjian zhushi. 
words we will consider, and most if not all are probably the result of unmotivated attraction toward high-frequency components during the evolution of pre-Qin easterly manuscript graph forms. Since the structures of both the xiaozhuan form and the very different guwen graph are partially or wholly opaque, the Han compiler of the Shuowen (assuming that the received Shuowen reflects his efforts at this point in the text) was unable to provide any plausible account of the graph: he suggests that it was a pictographic writing for the presumably homophonous shun 㢋 "hibiscus."17

\section{The Guodian Forms}

The exemplars from the Guodian tomb have allowed us to see more clearly what is going on, for the first time in almost two millennia. Even within that single collection of texts there is unmotivated variation reflected in the distinct habits of two scribes (Figure 3). The first scribe is responsible for the "Qiong da yi shi," while the second is the copyist of the "Tang Yu zhi dao." The two contrasting forms are used consistently within each manuscript.
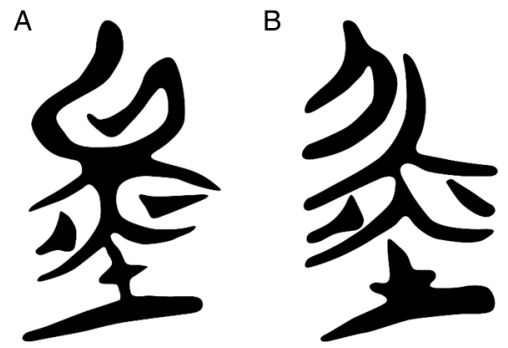

Figure 3. Two writings for Shun 舜 in the Guodian manuscripts; A. "Qiong da yi shi" strip 2, B. "Tang Yu zhi dao" strip 23.

The similarities to the guwen of the received dictionaries is immediately evident, particularly in Guodian form B. This is in keeping with the general observation that guwen graphs in received sources tend to have a distinctive pedigree in excavated texts from the Warring States period, and from the more easterly states (i.e. including $\mathrm{Chu}$, but not Qin). ${ }^{18}$

17. Xu Shen, Shuowen jiezi, 113.

18. For a more detailed and precise articulation of this correspondence between graph exemplars labelled "guwen" in received sources and pre-Qin scribal traditions, 
Intriguingly, what appears to be the same contrast as the one we see between forms A and B for 舜 recurs in forms of the character 疑 occurring at the same place in the text "Zi yi 緇衣" in the Guodian and Shanghai versions, where the received text has 疑 (Figure $4^{19}$ ). The similarity of the graphs for 疑 and 舜, and also for 矣 in these manuscripts has suggested to some palaeographers (in particular Wei Yihui) that the graphs share a common origin, deriving ultimately from the pictogram for $y i$ 疑 "to doubt, be uncertain," and that they do so because the words they wrote were similar in sound. ${ }^{20}$ This led Wei to conclude that Guodian form B is the original for 舜 since the corresponding form for 疑, E, is the more usual, and that forms $\mathrm{A}$ and $\mathrm{D}$ were secondary and derived from it.
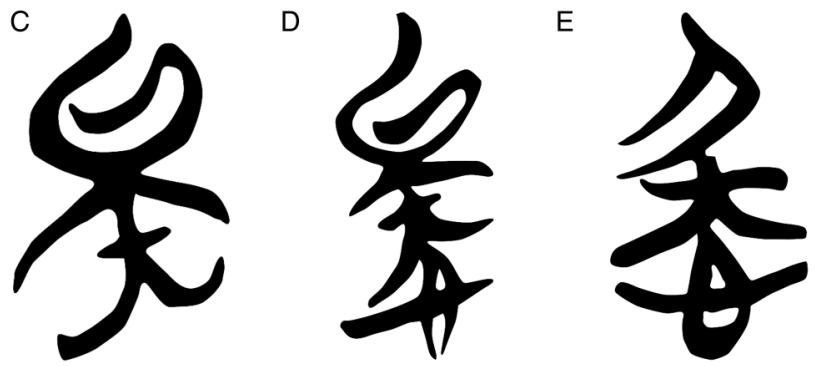

Figure 4. Manuscript forms for 矣 and 疑. C. 矣 from Guodian “Lu Mu Gong wen yu $\mathrm{Zi} \mathrm{Si}$ 魯穆公問於子思" strip 2; D. 疑 from Guodian “Zi yi 緇衣” strip 4; E. 疑 from Shanghai Museum “Zi yi" strip 2.

This is not in fact the case. The manuscript graphs for $y i$ 疑 and Shun 舜 are indeed similar, and show a similar alternation, but there is no similarity in sound between shun 舜 “Shun" and yi 疑 “doubt": initial, vowel, and coda all fail to match the conditions required for a shared regular phonetic spelling (for reconstructions, see below). The topmost element of form E for $y i$ 疑, which appears as 七 in the

see Zhang Fuhai 張富海, Hanren suowei guwen zhi yanjiu 漢人所謂古文之研究 (Beijing: Xianzhuang, 2007).

19. Jingmenshi Bowuguan, Guodian Chu mu zhujian, 17, 23; Ma Chengyuan 馬承源, ed., Shanghai Bowuguan cang Zhanguo Chu zhushu (yi) 上海博物館藏戰國楚竹書 (一) (Shanghai Guji, 2001), 46.

20. For the proposal that writings for yi 疑 “doubt" and Shun 舜 share a common phonetic spelling, see Wei Yihui, "Shixi Chujian wenzi zhong de 'yi' yu 'Shun' zi"; for alternative views, see Chen Sipeng, "Guodian Chujian jiedu si ze"; for the 疑 pictogram, a figure with an old person's cane wandering in a state of gaping confusion, see Guwenzi Gulin Bianzuan Weiyuanhui 古文字詁林編纂委員會, ed., Guwenzi gulin 古文 字詁林 (Shanghai Jiaoyu, 1999), 10.1094-96. 
received orthography, is the more frequently seen, and likely to be original. Form $\mathrm{D}$ is probably the result of unmotivated attraction, perhaps toward form C. Notice also that the element which appears as 矢 in the received orthography for $y i$ 疑 and $y i$ 矣 is kept slightly distinct from the similar-looking element in the forms A and B for Shun 舜.

Guodian form A is the more conservative writing for Shun, preserving one crucially informative component intact: the topmost element is 允, a phonetic spelling for the name Shun. ${ }^{21}$ Not only is there a good visual match with the graph 允 in the same corpus, and a good phonological match (for which see the next section), but multiple other lines of evidence support the identification, and a whole suite of problems can be resolved from this starting point (Figure $5^{22}$ ).
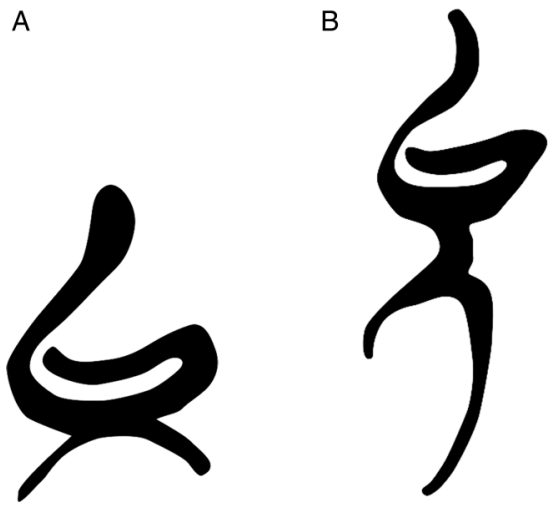

Figure 5. 允 in the Guodian manuscripts "Cheng zhi wen zhi" 成之聞之 strips 25 (A) and $36(\mathrm{~B})$.

\section{Di Jun 帝俊 in the Shan hai jing 山海經}

Since at least the time of Guo Pu's 郭璞 (276-324 C.E.) commentary, it has been recognized that the Shan hai jing contains narratives that are elsewhere associated with Shun 舜 but which that text associates with a name written Di Jun 帝俊 “Thearch Jun." ${ }^{23}$ The graph jun 俊 has 允 (in 夋)

21. Ji Xusheng, “Du Guodian, Shangbo jian wu ti"; Ma Chengyuan 馬承源, Shanghai Bowuguan cang Zhanguo Chu zhushu (er) 上海博物館藏戰國楚竹書（二） (Shanghai Guji, 2002), 187-88.

22. Jingmenshi Bowuguan, Guodian Chu mu zhujian, 51.

23. Ji Xusheng, "Du Guodian, Shangbo jian wu ti," 114-16; Sarah Allan, The Shape of the Turtle: Myth, Art, and Cosmos in Early China (Albany, NY: State University of New York Press, 1991), 33-35. 
as a component, and from the Guodian evidence we know that this is shared with a writing for Shun 舜. This confirms that, rather than the confusion of two similar sounding names, 舜 and 俊 are alternative writings of the same name, as Guo Pu had originally stated. Notice, however, that MC sources such as the Guangyun assign different phonological values (specifically, different initials) to these two graphs: 俊 only gets the reading jun $<$ tswinH, and never shun $<$ sywinH.

This absence of a reading shun for 俊 in the Guangyun may be due to the relative obscurity of the Shan hai jing during the medieval period. ${ }^{24}$ Since that text seems to be the only extant witness to the use of 俊 to write Shun, the compilers of the rhyme books may only have considered the more widespread pronunciation of 俊 in the sense "eminent person." The Jiyun 集韻, however, does list the graph 俊 as a homophone of, and alternate writing for, Shun 舜, presumably to accommodate the Shan hai jing occurrences. ${ }^{25}$ At the same time, jun "eminent person" also seems to provide a possible etymology for the name Shun. The fact that 俊 as a writing for Shun is confined to a single text presumably has implications for understanding the transmission of the Shan hai jing, specifically the orthographic tradition and (if the distinct MC pronunciations of jun and shun are of a single origin) perhaps the dialect in which the transmission took place. This will not be pursued here, however.

It seems likely that jun 俊 “eminent person" is the same word as jun 駿 "eminent horse," and perhaps also jun 畯 "farm foreman"; all have the same MC reading and the same spelling with 允 (in 夋), and as just suggested they may also hint at a possible etymology for the name Shun. However, there is a complication: they are all irregular spellings in the Baxter-Sagart phonological system to which we are committed for the purposes of this presentation. As we will see below, 允 is a regular speller for OC words with lateral initials. The MC initial ts- (jing 精 in the traditional terminology) never reflects an OC lateral initial under Baxter-Sagart.

Therefore, we need to mark the irregularity and to reflect on which of the several possible responses outlined in the methodological preliminaries above might be viable in this instance. If the family of words meaning "eminent individual" originally also had a lateral initial of some kind, either the MC ts- initial represents a dialectal development followed by a loan into the common reading tradition, or it should be

24. Riccardo Fracasso, "Shan Hai Ching 山海經," in Early Chinese Texts: A Bibliographical Guide, by Michael Loewe (Berkeley, CA: Society for the Study of Early China, Institute of East Asian Studies, UC Berkeley, 1993), 357-67.

25. Ding Du 丁度 (990-1053 C.E.), Song ke Jiyun 宋刻集韻, ed. Beijing Tushuguan 北 京圖書館 (Beijing: Zhonghua, 1989), zhun yun 稕韻, p. 154. 
taken as an invitation to extend or modify the Baxter-Sagart model for the development of lateral initials. ${ }^{26} \mathrm{~A}$ resolution would require collecting additional examples of OC laterals showing up as $\mathrm{MC}$ ts-, but that is beyond the scope of this article.

Notice, also, that jun 俊 (and qun 夋 etc.) has the inverted foot pictogram, 女, below 允. This provides a partial but nevertheless significant parallel with the paired inverted feet, 舛, at the bottom of the xiaozhuan-derived received form for Shun 舜. This has been noted in the scholarship cited above, but no satisfactory account of the presence of the foot element has been offered. Since it appears relatively early, and in bronze inscriptions (a non-cursive medium), it is unlikely to be the result of graphic attraction, and we should therefore expect it to have a semantically motivated function in writing a word that could regularly spelled with 允 or 夋 (Figure 6 $6^{27}$ ). Although the structure of the graph in this figure is clear, the word being written is less obvious.

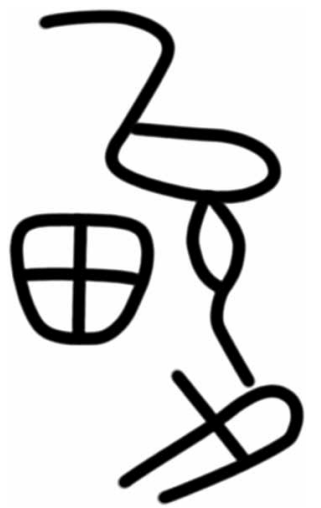

Figure 6. The graph 畯 in Qin Gong bo 秦公鎛 (JC263), early Springs and Autumns.

As is well known, the foot pictogram is a common component in graphs writing verbs of motion, and the inverted foot is used in particular for verbs of retrograde motion. Common examples include $f u$ 復 “to return," lai 來(麥) “to come," zhi 致” to bring, deliver," tui 退 (originally 僈) “to withdraw," and hou 後 "to lag behind." The foot pictogram also

26. As Wolfgang Behr has pointed out to me, in the OC reconstruction of ZhengZhang Shangfang, MC ts- can regularly reflect OC clusters with *1-: Zheng-Zhang Shangfang 鄭張尚芳, Shanggu yinxi 上古音系 (Shanghai Jiaoyu, 2003), 104-9, 227.

27. Zhongguo Shehuikexueyuan Kaogu Yanjiusuo 中國社會科學院考古研究, Yin Zhou jinwen jicheng 殷周金文集成, 18 vols. (Beijing: Zhonghua, 1984) \#263. 
appears in writing verbs meaning "to be still," most obviously zhi 止 "to stop," but also chu 處(処) “to dwell, settle, stop."

Reviewing the vocabulary phonetically spelled with 允 or 夋 for candidate verbs of motion, we find one possible fit in the following verb, which appears with a number of different writings, and as either a single syllable or in a disyllabic reduplicated form:

qun 䢬 "withdraw" 28

qunxun or qunqun 逡巡 夋夋 逡遁 蹲巡 “to withdraw, move to and fro (in hesitation, etc.)"

It is possible, then, that the inverted foot was originally semantically motivated, and was put together with the phonetic speller yun 允 in order to write qun(xun), after which the combination then became the phonetic speller for a series of its own (夋, 逡, 俊, etc.).

An alternative possibility, of an unmotivated addition to the graph 允, is suggested by the writing for the word yun 允 "indeed," which appears in a number of Warring States-period excavated texts (Figure $7^{29}, 3^{\circ}$ ). In these, the graph 允 is embellished with a couple of additional strokes resembling those for 女, but which also have a passing resemblance to those of $⿻ 上 丨$.
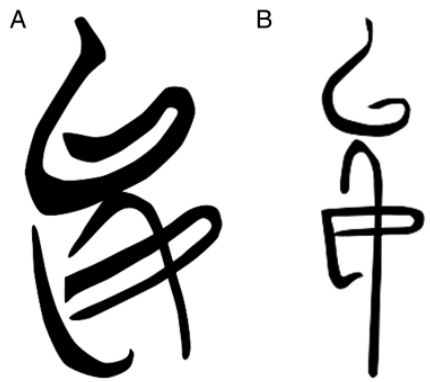

Figure 7. Writings for yun 允 “indeed, truly," embellished with 女. A. Tsinghua “Cheng wu" 程䠽 strip 8; B. Zhongshan wang 14th year fang $h u$.

This brings us about half way toward a complete account of the diversity of writings for Shun that are now known, which we can

28. As will become clearer subsequently when we consider the phonological reconstruction of this word, it is likely also to be related to dun 遁 遜 "run away, flee."

29. (7 A) Qinghua Daxue Chutu Wenxian Yanjiu yu Baohu Zhongxin 清華大學出土 文獻研究與保護中心, ed., Qinghua Daxue cang Zhanguo zhujian (yi) 清華大學藏戰國竹簡 (壹) (Shanghai: Zhongxi shuju 中西書局, 2010).

30. (7 B) Zhongguo Shehuikexueyuan Kaogu Yanjiusuo, Yin Zhou Jinwen Jicheng, \#9735. 
summarize as follows. 夋 may have been coined to write the verb of motion qun(xun), and has 允 as its phonetic speller. It in turn serves as the phonetic speller in 俊 as a writing for "Shun" in the Shan hai jing. The doubled inverted feet 多 in the xiaozhuan-derived 舜 may also be connected with the inverted foot in the writing for qun(xun) "withdraw; move to and fro (in hesitation, etc.)." The top half of the xiaozhuan writing remains hard to account for: conceivably a 允 (or a doubled 允?) contributed, but this is not transparent in any exemplars. Guodian form A (Figure 3) clearly has 允 as its topmost component. Form B seems to be either a mirror-image of form $\mathrm{A}$, or the result of attraction toward 疑 (Figure 4 D, E), in which the originally phonologically motivated 允 has been obscured if not altogether reinterpreted. The lower parts of the Guodian graphs are still hard to account for: there appears to be a 土 of unclear motivation at the bottom of the stack, while the middle strokes appear to be have parallels in the xiaozhuan form. The received guwen forms of the Shuowen and the Hanjian (Figure 2 B, C) are closest to Guodian form B.

\section{The Challenge of guwen}

From the point of view of the general history of early Chinese literacy, this example illustrates how remarkably free to drift the appearance and componential structure of graphs were during the period when the Warring States manuscripts were produced. Graph components whose roles were a few centuries earlier transparently motivated in terms of iconicity, semantics, or phonology, were allowed to change and merge with one another, apparently without any restraint other than the immediate demands of contemporary legibility by scribes and readers. In particular, the Warring States manuscript copyists often give the impression of working outside the constraints of a prescriptive model of historically or analytically correct graph forms. It seems unlikely that the learning process that produced the orthography of, say, the "Tang Yu zhi dao" copyist (Guodian form B) was informed by a sign-list conservatively inherited across centuries. He was probably less aware of why Shun's name was written as he wrote it than we-with the benefit of palaeographic results-are now. Neither the phonetic speller yun 允 nor any other clearly motivated component (like the foot pictogram), are preserved in his writing of the word. Rather, knowledge of the script seems to have been acquired through familiarization with the contemporary visual flux of graph forms.

Here we begin to see in concrete illustration why the guwen texts proved such a challenge to Han scholars. They valued them as distinctive textual witnesses against which their existing versions could be 
compared. But the reason why they were orthographically difficult for Han readers was not because they preserved graph forms that were in some sense pristine, original, or conservative, in contrast to an obscured and debased contemporary script-something which the Western Han sources themselves never claim. On the contrary, they were difficult because they were the product of a manuscript tradition that had been through a period of rapid graphic evolution and innovative departure from the earlier script of the Zhou court, which had resulted in an orthography that was less transparently analytic. ${ }^{31}$ The Han-period script was direct heir to the Qin standard. It was carefully maintained through a lineage of lexical texts that reached directly back to the period of the Qin empire and thence to the historically conservative and analytic script of Qin prior to unification. Liu Xin's 劉歆 bibliography of the Han imperial library lists a number of Qin Empire-period lexical texts, including the Cangjie pian 倉頡篇 in seven chapters, compiled by the Qin chancellor Li Si 李斯, stating explicitly that these were compiled with reference to a still older lexical text that was used by scribes of the Zhou court to teach children. That text, the Shi Zhou pian 史㰖篇, the oldest Chinese lexical text whose existence we know of, was listed as extant in Liu Xin's catalog, and was sufficiently well preserved in 100 C.E. for $\mathrm{Xu}$ Shen to incorporate 223 of its graph forms into his own compilation. ${ }^{2}$

What is remarkable is the complete absence, from the Han library, from the entirety of received literature, and from excavated sources, of any kind of pre-Qin lexical text, or reference to one, that could have constituted a standard for the eastern manuscript orthographies that Han scholars were struggling with under the term guwen. ${ }^{33}$ The careful

31. Examples of specifically Chu manuscript innovations, both structural and cosmetic, are discussed in Haeree Park, The Writing System of Scribe Zhou: Evidence from Late Pre-Imperial Chinese Manuscripts and Inscriptions (5th-3rd Centuries B.C.E.) (Berlin: Walter de Gruyter, 2016), ch. 4.

32. For a defense of the traditional late Western Zhou date of the Shi Zhou pian, see Qiu Xigui, Chinese Writing, 72-77; for a revision of the traditional date to 350 years later, see Pan Yukun 潘玉坤, “Shi Zhou pian niandai kao 史㰖篇年代考," Hangzhou Shifan Xueyuan Xuebao 杭州師範學院學報 2 (2005), 82-85, 102; a useful review of the question is given in Li Yunxin 李蕓金鉷, “Zhouwen shidai wenti yanjiu zongshu 籀文時代問題研 究綜述," Fudan Daxue Chutu Wenxian yu Guwenzi Yanjiu Zhongxin 复旦大学出土文献与 古文字研究中心, October 30, 2015, http:/ /www.gwz.fudan.edu.cn/Web/Show / 2616.

33. It will be interesting to see whether this claim will still hold good after the publication of the Zixi 字析 “Analysis of graphs" text in the Shanghai Museum collection, said to be a Warring States-period Chu manuscript. Pu Maozuo 兴茅左, “Shanbo guancang Zhanguo Chu zhushu de zhuyao faxian 上博館藏戰國楚竹書的主要發現, "Wendang tiankong 文檔天空, 2007, http://www.documentsky.com/2852325295/. If I were to hazard a guess based on the very limited descriptions provided so far, and on what 
collection and preservation of guwen graph forms that were part of $\mathrm{Xu}$ Shen's dictionary project, which continued with the mid-third century C.E. "Three Script" stele inscriptions of canonical texts (San ti shi jing 三 體石經) and in much later endeavors like the Hanjian and Guwen sisheng yun, can be seen as, in a sense, making good the gap left by the missing pre-Qin eastern-state lexical texts.

Should the absence of these lexical texts be understood as their failure to preserve and be transmitted, or is it an indication that guwen writing was the product of a manuscript tradition that was not constrained, even on a regional level, by authoritative, institutionalized, analytic, and diachronically stable standards of orthography, of the kind that the Zhou court and the Qin state had successively sustained? I have already suggested that the latter is likely to have been the case, because of the rapid degree of change, including attraction, that affected graphs used in eastern manuscripts. Of course, this doesn't mean that the eastern texts were produced without any kind of orthographic norms at all. The requirements of legibility would preclude that. But it does imply that de facto standards were established with reference to the contemporary, drifting state of the script-scribes adopting the practices of their contemporary senior colleagues-instead of scribes calibrating their hands with reference to a fixed set of historical graph exemplars.

The difference between these two ways in which script norms can be established-copying one's contemporaries vs. copying a fixed standard - can be seen very clearly in the degree to which Han-period management of the script was able effectively to freeze the graphic repertoire to produce the orthographic standard that served China and much of East Asia for two millennia, with only modest and fundamentally cosmetic changes. 34 This was achieved by a tradition of enduring, publicly-visible text-bearing stone monuments, the

we already know about Warring States Chu manuscript writing, it would be to predict that the standard reflected in this text will not be that of the innovative manuscript tendencies of its own period, but more conservative norms from several centuries earlier. Regardless, its publication will be interesting for the continued discussion of the questions raised here.

34. Of course, this is not to say that the spoken language of Han period was similarly frozen, along with the orthography. The fact that an Eastern Han stele is orthographically transparent to a later reader is no guarantee that the syntax and vocabulary will be accessible, or that a later reader will pronounce it the same way as its author. The continuing prestige and currency of prose texts from the Warring States and Han periods did much to define a prose standard for certain categories of formal written text in subsequent periods, but this is a distinct phenomenon from the fixing of the script. 
maintenance of lexical texts, and an ingrained expectation that correct orthography have an analytical basis. The Han shared a tradition of public inscribed stone monuments most closely with their Qin predecessors, ${ }^{35}$ and as we have seen, the Han lexical texts represent an unbroken continuity with the Qin tradition. It is more difficult to know whether there were precursors to the explicitly articulated analytical justification for orthography, documented graph-by-graph, which we see in Xu Shen's compilation of the Shuowen. But certainly, we see little sign of anything similar to these three traditions among the eastern states of the Warring States period.

Notice also that this permanent and universal fixing of the script standard did nothing to hinder the development and use of brush-written, cursive forms that were as visually different from the standard and as minimally analytic as any graphs seen in Warring States manuscripts. However, no one produced these cursive forms without being fully immersed in a tradition of literacy that took the Han standard for granted. No one learnt the script from caoshu exemplars.

In order to emphasize just how challenged Han readers were by orthographies that lay outside the Zhou-Qin-Han line of descent, let us examine some of the further ramifications of the identification of the Shun 舜 graph discussed above. This is at the same time an opportunity to emphasize how, through the wealth of palaeographic evidence that is now available to us, and the use of palaeographic and linguistic tools, we now in many cases have a much clearer perspective on the historical trajectories undergone by the script than the early Chinese scribes who maintained it. We can answer questions of a kind that they posed but were unable to answer.

\section{The Phonology of Shun and Other Words Spelled with 允}

To see clearly what is going on in a number of the problems that follow, we need to be clear about how the words in question relate to one another phonologically and to their phonic spellings in the script. As discussed above, the Guodian manuscripts together with the writing for the sage-king's name in the Shan hai jing have made it clear that Shun may be spelled with 允 (sometimes in the form of the compound qun 夋). If we consider the behavior of 允 and 夋 as phonetic spellers more generally, we find that we need to reconstruct the words they spell with a

35. Martin Kern, The Stele Inscriptions of Ch' in Shih-Huang: Text and Ritual in Early Chinese Imperial Representation (American Oriental Society, 2000). 
syllable of the basic shape *lun, i.e. with a lateral main initial and the rhyme *-un. Relatively straightforward examples from this series include the following.

$$
\begin{aligned}
& \text { 允 yǔn }<y \text { win } X<*^{*} \text { lun? “(adv.) truly; (adj.) trustworthy, true."36 } \\
& \text { 吮 shǔn }<z y \text { win } X<{ }^{*} \text { Colun? or *m-lun? "(v.) suck."37 } \\
& \text { 峻 陖 陖 xùn < swinH < *slun "(adj.) high, precipitous (of buildings, } \\
& \text { mountains, cliffs)." } 38 \\
& \text { 逡循～逡遁 逡巡 qūn-xún < tshwin-zwin < slun-solun “(v.) withdraw, } \\
& \text { move to and fro (in hesitation, etc.)." } 39
\end{aligned}
$$

Taken together, these forms provide strong evidence that the syllable of "Shun" 舜 should also be of a similar form..$^{\circ}$ The following reconstruction is entirely regular within the systems of Baxter and

36. Baxter and Sagart ("version 1.1") offer an agnostic reconstruction of *[1]u[r]?. I don't see any reason to reconstruct a coda ${ }^{*}$-r in this word or any other spelled with 允. The evidence of the series as a whole indicates that we can remove the square brackets around initial ${ }^{*} 1$.

37. Baxter and Sagart do not offer a reconstruction of this word in any of their word lists. Either of the two forms I provide would be regular in their system, however. I see no evidence to choose between the two, but for present purposes, the presence of the lateral initial is what we want. Schuessler (Etymological Dictionary, p. 476) offers ${ }^{*}$ m-lun?.

38. Neither Baxter and Sagart, nor Schuessler offer a reconstruction of this item, although the reconstruction given here would be regular within their systems.

39. Neither Baxter and Sagart, nor Schuessler offer a reconstruction of precisely this item. However, Baxter and Sagart's (New reconstruction p. 251, and "version 1.1") reconstruction of 遯 遁 dùn "withdraw; retreat; go into hiding" is " $\mathrm{I}^{\mathrm{f}} \mathrm{u}[\mathrm{n}]$ ? and must surely be a member of the same family of words. Words spelled with 盾 and 川 (as in 巡 above) they consistently reconstruct with a syllable of the basic form *lun (i.e. disregarding initial devoicing, pre-initials, type A vs. type B, etc. which are not implicated in phonological spellings). We receive remarkable confirmation that chuan 川, dun 盾 and shun 舜 spell words with the same syllable core through a fortunate preservation in the Hanjian and Guwen sisheng yun. Those texts preserve a form under the head graph 巡 that has the guwen form of the graph shun 舜 as its phonetic speller (Li Ling and Liu Xinguang, Hanjian, Guwen sisheng yun 4, 17). Finally, it is worth remarking that, although the form slun-səlun is probably the notation that we should retain for the sake of clarity, and fulfills the purpose here well enough, it is likely that disyllabic words of this kind began as simple reduplications, perhaps a more natural-looking slun-slun, and that the voicing and deaffrication in MC of the second syllable is due to assimilation.

40. We have already mentioned the irregularity of spellings like jun 俊 “distinguished person" within the Baxter-Sagart system. Lacking for the time being a complete solution to this problem, I do not try to provide reconstructions for them here. Baxter and Sagart ("version 1.1") offer 駿 jùn < tswinH < *[ts]ur-s "fine horse," with agnostic brackets. Their motivation for explicitly reconstructing *-r rather than *-n here is not clear to me. 
Sagart, and Schuessler, and thereby reinforces the conclusion that 夋 or 允 may be regular spellings for "Shun."

舜 shùn $<$ sywinH $<$ luns "Shun"41

\section{Zheng Xuan's Comments on the Name "Shun"}

As a first and simple example of the clarity that results of this kind can bring, potentially changing the way in which we read familiar texts, consider the phrase that ends these words of praise for Shun's governance, put into the mouth of "The Master" by the author of the Zhongyong.

舜其大知也與! 舜好問而好察邇言, 隱惡而揚善, 執其兩端, 用其中於 民，其斯以爲舜乎！

There was Shun: He indeed was greatly wise! Shun loved to question others, and to study their words, though they might be shallow. He concealed what was bad in them and displayed what was good. He took hold of their two extremes, determined the Mean, and employed it in his government of the people. It was by this that he was Shun! ${ }^{42}$

What the final phrase seems to be saying is that all the previously described behaviors and their social consequences are the reason why Shun became the famed sage-king that we know by the name "Shun." However, Zheng Xuan's commentary on the passage makes a puzzling remark:

$$
\text { “舜 “之言”充”也。 }
$$

The word "shun 舜" is "chong 充 full."43

This makes little sense in the context. The Tang commentators (to whom we owe the received text of Zheng Xuan's commentary) take it at face value, as a statement of the "fullness" of Shun's moral qualities ("dao de chong man 道德充滿”), which still makes little sense of the original passage, and none at all of Zheng Xuan's equation: when does shun 舜 ever mean "full"? With remarkable insight, the nineteenth-century scholar Zhu Junsheng 朱駿聲 in his phonological commentary on the Shuowen,

41. Neither Baxter and Sagart, nor Schuessler give a reconstruction for the name of sage-emperor Shun. Baxter and Sagart give *[s.t]u[n]-s for the probably homophonous shun 舜 夢 “hibiscus."

42. Shisanjing Zhushu Bianweihui 十三經注疏編委會, Liji zhengyi (Shisanjing zhushu zhengli ben) 禮記正義 (十三經注疏整理本), 4 vols. (Beijing Daxue, 2000) 52.1665; James Legge, The Chinese Classics, 2nd rev., vol. 1 (Oxford: Clarendon Press, 1893), 388.

43. Liji zhengyi 52.1665. 
stated that the received text was in error and that the word in Zheng Xuan's gloss was not chong 充 "full" but its lookalike yun 允, perhaps in the sense "true, of good faith." 44 Zhu's correction is especially remarkable without the evidence from Guodian that yun 允 was regularly used to spell the name "Shun." Zheng Xuan, on the other hand, may perhaps have been aware of the relationship through consideration of guwen exemplars to which he had access. Admittedly, Zheng Xuan's understanding of the original expression in the Zhongyong, "That is why he was taken to be 'shun'," would still not be fully compelling: it is not obvious that Confucius' description of Shun is talking about "fidelity," if that is what Zheng meant by yun 允. Nevertheless, our knowledge of palaeography and phonology allows us a glimpse of a text through a Han scholar's eyes and ears, as well as a sense of what he thought he was doing, specifically reading shun as an adjective and supplying a graphic and phonological gloss, all of which was misunderstood by his Tang readers.

\section{A guwen Survival in the Received Gongyang zhuan 公羊傳: shun 瞬 “blink"}

As a final example of how very recent palaeographic results allow us to resolve longstanding problems that confused Qing, Song, Tang, and Han investigators, consider the following word, likely an OC homophone of sage-king Shun.

$$
\text { 瞬～瞚 Shùn }<\text { sywin } H<\text { *luns “(v.) wink; blink"45 }
$$

The graph 瞬 is currently the standard writing for this common word, and an informal survey of dictionaries and electronic corpora indicates that this has been true for the last 1,00o years or so. However, earlier received texts seem to show an alternation between this graph and a second writing, 演, for the same word. The Shuowen, as it has come down to us, contains only the second writing, with no remark about any variants, and with an apparently explicit statement that yin 寅 is the phonetic speller. If one were to take this situation at face value, as previous treatments have generally done, one would conclude that the second writing is the earlier, and that there had been a change in the phonetic

44. Liao Mingchun 廖名春, Xinchu Chujian shilun 新出楚簡試論 (Wunan Tushu, 2001), 260 .

45. Schuessler (Etymological dictionary) gives *hwins for this word. However, as the discussion here shows, the phonetic spelling with 舜 is old, and 寅 spurious. If shun 舜 had a lateral initial and the *-un rhyme, then shun 瞬 "blink" is likely to have had them also. 
speller, from yin 寅 to shun 舜. ${ }^{46}$ Cases like this can be valuable for tracking sound changes that invited an updated spelling.

But that is not what is going on with this word. The first thing to note is that yin 寅 cannot be a regular spelling for a word with the $\mathrm{MC}$ reading sywinH, which indicates an OC rounded vowel (as in *-un, in this case). $Y$ in 寅 spells words with OC unrounded vowels. 47 Our methodological commitment to explaining, or explaining away, irregular spellings means we have to address this, rather than dismissing it as normal loose spelling.

The solution lies in comparing the guwen (that is, pre-Qin, eastern, manuscript) forms for shun 舜 which we have already discussed (Figure 2 B, C; Figure 3), with forms for yin 寅, and their compounds (Figure 8).
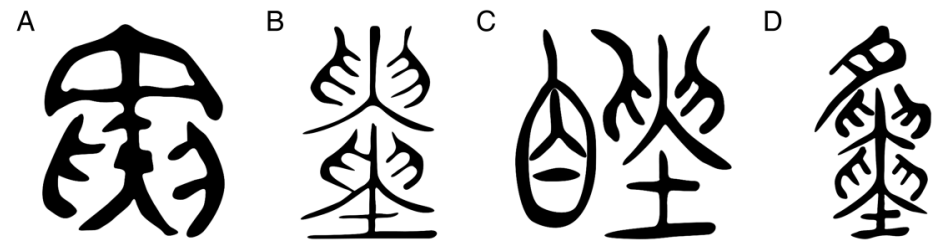

Figure 8. yin 寅 and its compounds: A. yin 寅 bronze inscription, c. 80o B.C.E. (Yin Zhou jinwen jicheng \#4280); B. guwen yin 寅 (Shuowen jiezi); guwen 瞚 (Hanjian p. 8); guwen 勇 (Guwen sisheng yun p. 16).

The visual similarity between the two components, and their potential to be misinterpreted one for the other (or "attracted"), is clear. This was first noted by Huang Xiquan 黄錫全, who stated, without any knowledge of what was to come from Guodian, and with no phonological apparatus to speak of, that the guwen form for Shun 舜 in the Hanjian was “likely a corruption of yin 勇 or of shun 瞚." 48 He was fundamentally insightful, but we can now tighten up his statement.

46. Duan Yucai takes this position, incorrectly as it turns out. Duan Yucai, Shuowen jiezi zhu, 135 .

47. Duan (Shuowen jiezi zhu, p. 135) noted this contradiction. Traditional Chinese phonology recognizes it, usually placing yin 寅 in the OC zhen 真 rhyme, and shun 舜 in the wen 文 rhyme. Wang Li 王力 (Wang Li gu Hanyu zidian 王力古漢語字典. [Beijing: Zhonghua, 200o]) responds to it by tacitly placing shun 瞚 into the zhen 真 rhyme, in accord with its apparent spelling, but in contradiction to its $\mathrm{MC}$ reading. The reasoning presented here provides a resolution, as well as a correction to Wang Li.

48. Huang Xiquan 黄錫全, Hanjian zhushi 汗簡注釋, 219; Wei Yihui 魏宜輝, “Shixi Chu jian wenzi zhong de 'yi' yu 'Shun' zi 試析楚簡文字中的“疑'與'舜'字, ” 161, disputes Huang's identification, but as noted above, Wei's position on the question can be completely ruled out on phonological grounds. 
Yin 寅 and shun 舜 are in origin two entirely unrelated graphs. The words they spell form non-overlapping and phonologically incompatible sets: a single phonetic speller cannot regularly spell words in one of the two sets. In its earliest second millennium B.C.E. forms, yin 寅 appears as an upward-pointing arrow-like element, sometimes flanked by a pair of grasping hands. The pictographic motivation for this combination is obscure. Shun 舜, as we have seen, is variously written with combinations involving yun 允, 夋 (as phonetic spellers) and chuan 舛 (possibly semantically motivated through the writing for the word qunxun 逡巡 "to withdraw; hesitate"), together with other poorly understood elements.

For reasons that are not clear, both yin 寅 and shun 舜 get elaborated with what resembles a $t u$ 土 at the bottom of the graph in some excavated manuscript and transmitted guwen sources. Some manuscript copyists, as we have seen, mirror-reverse the yun 允 in shun 舜, rendering it unrecognizable. This suite of changes is part of a general trend of falling-together of distinctions and loss of analyticity in the eastern manuscript orthographies. We have already noted the visual proximity of shun 舜 to $y i$ 疑 and yi 矣. Yin 寅 also joined this lookalike group.

When Han or later scholars aimed to reimpose an analytic interpretation on graphs from guwen sources, or transcribe them into their analytic orthographic standard, they were obliged to make decisions. They had to decide what graphic analysis the guwen scribe "should" have adopted. As the preceding discussion should have made clear, that decision often could not be made on the basis of the guwen forms themselves, since many distinctions had already collapsed or become opaque through "attraction" and other processes. What it required was a deep perspective on palaeographic history, which the twenty-first century now has in greater measure than Han investigators did. The Shuowen entry for 瞬 is evidently based on a mistranscription of a guwen writing for the word. In transcribing and analyzing it as shun 瞚, the wrong decision was made, because of the visual similarity of the guwen forms for yin 寅 and for shun 舜, and the error became embedded in the Shuowen dictionary. 49 Since the usage is widespread in received early texts, the mistranscription probably did not begin with the Shuowen, which was presumably reflecting current usage.

49. As previously remarked, the received Shuowen is not an unproblematic reflection of the Eastern Han text. The mistaken reanalysis of shun 瞬 as shun 瞚 may conceivably have been a later addition or modification by an editor. Nevertheless, the Song editor Xu Xuan 徐鉉 seems to have accepted it as original, and the correct analysis, stating, "Nowadays, the common custom is to write the different form shun 瞬, which is incorrect. 今俗别作瞬, 非是。” 
When we refer to guwen texts, we are normally following Han usage and referring specifically to old manuscripts which resurfaced during the Han period, and which contrasted orthographically with then-current versions. But the rediscovered guwen texts are not the only editions circulating during the Han that contain written forms that reflect preQin eastern manuscript graphs. The Gongyang zhuan 公羊傳 is not a guwen text: there was no Han-period discovery of an early version that could be compared with a current version. Nevertheless, it has a distinctively eastern (specifically Qi 齊) transmission pedigree that seems to reach back prior to the Qin conquest, through the Gongyang family for whom it is named, and forward to the inheritor of their tradition, Erudite Scholar (bo shi) 博士 Hu Wusheng 胡冊生, who, according to He Xiu's 何休 (129-182 C.E.) commentary, first set the tradition into writing during the reign of Jing Di 景帝 (r. 157-141 B.C.E.).50

The following difficult passage from the Gongyang zhuan (quoted with the corresponding Chunqiu entry) contains an exceptional writing for a word meaning "blink" that would be impenetrably obscure without reference to what we have already established in the preceding discussion about eastern manuscript spellings involving shun 舜.

秋, 八月, 公會諸侯、晉大夫, 盟于扈。

Autumn, 8th moon, the Duke [of Lu] convened with the Many Lords and the High Officer of Jin [Zhao Dun], and they swore an oath at Hu.

諸侯何以不序? 大夫何以不名? 公失序也。公失序奈何? 諸侯不可使與 公盟, 眣晉大夫使與公盟也。(Gongyang zhuan Wen 7) $)^{51}$

Why are the Many Lords not listed in rank order? Why is the High Officer not named? Because the Duke [of Lu] missed the listing. When the Duke missed the listing, what was to be done? The Many Lords could not be made to swear the oath with the Duke, but they "gave the wink" [眣] to the High Officer of Jin to have him swear the oath with the Duke.

There are many questions about this passage, which the commentaries on the Chun qiu traditions invest effort in addressing. ${ }^{22}$ But here we

50. For He Xiu's account, see Shisanjing Zhushu Bianweihui 十三經注疏編委會， Chunqiu Gongyang Zhuan zhushu (Shisanjing zhushu zhengli zen) 春秋公羊傳注疏（十三 經注疏整理本) (Beijing Daxue, 2000), 5. For Hu Wusheng and transmission history of the Gongyang zhuan, see Sima Qian 司馬遷 (c. 145-86 B.C.E.), Shi ji 史記 (Beijing: Zhonghua, 1959), 61.3118, 61.3128; Ban Gu 班固 (32-92 C.E.), Han shu 漢書 (Beijing: Zhonghua, 1960), 30.1712-15.

51. Shisanjing Zhushu Bianweihui, Chunqiu Gongyang zhuan zhushu, 336.

52. I am grateful to Joachim Gentz for clarifying many of these for me. 
need focus only on the word translated above as "gave the wink," and its graph in the Gongyang zhuan, 眣. In some editions the graph appears as 䀢, but written either way the graph is unique to the Gongyang zhuan (it also appears a second time in the same sense in the second year of Duke Cheng). 53

He Xiu, commenting on the Wen 7 passage, states:

以目通指曰 “眣”。

To convey an indication with the eyes is what is meant by 眣. 54

Semantically, this is a very good match for shun 瞬 "wink; blink," but He Xiu provides no indication of the pronunciation of this word, nor is it obvious from the graph itself that it should be pronounced shun, especially since neither shi 失 nor shi 矢 could be a regular phonetic speller for shun "blink." The Guangyun dictionary gives the graph as 䀢, stating that the source is the Gongyang zhuan, and identifying the word in question, unequivocally, as shun 瞬 "wink; blink." The corresponding Jingdian shiwen 經典釋文 entry states that the word is "pronounced shun 舜", before listing variants in other editions and lexical texts.

[䀢]音舜。本又作 “眣” , 尹乙反, 又大結反。以目通指曰 “眣” 。本 又作 “䀵”, 音同。《字書》云: “眣, 瞚也。以忍反”。55

䀢: pronounced shùn <sywinH. According to some editions, it is written 眣 and read $y i<y i t$, or dié < det. To convey an indication with the eyes is what is meant by 眣. In some editions it is written 䀵, with the same pronunciation. According to the Zi shu [Book of graphs, an early dictionary, now lost save for citations in other works]: “眣 is the same as 瞚 'to blink,' read y̆n < yinX."

Clearly, there were a range of opinions regarding this word in the late sixth century when the Jingdian shiwen was compiled. The semantics of the word were not in dispute, but the variant readings appear to be guesses about the probable phonetic speller. However, it is the preservation of the form 䀵 (only via this Jingdian shiwen entry, as far as I am aware) that allows us to resolve the problem decisively using our knowledge of Warring State period manuscript forms.

Recall that one of the Guodian forms for "Shun" (Figure 3 A) was visually very close to the Guodian writing for 矣 (Figure $4 \mathrm{C}$ ). The 矣 of 䀵 was thus, in origin, a compound involving 允 and a regular phonetic

53. Shisanjing Zhushu Bianweihui, Chunqiu Gongyang zhuan zhushu, 434 .

54. Ibid., 336 .

55. Ibid., 336 . 
speller for the word shun 瞬 "wink; blink," in current use close to the time when the Gongyang zhuan was first set in writing, but which underwent "attraction" toward the commonly encountered form 矣 used to write the familiar sentence final particle. The forms 䀵, 演, 眣, and 䀢 all derive from variations and simplifications of this same phonetic spelling. Without our knowledge of the Warring States-period manuscript writings of "Shun" that first became available through the Guodian discoveries, we would still be at a loss as to how best to account for these forms, much as scholars in medieval China were.

竹簡寫本 “舜” 字的不同字形, 以及傳世文獻中戰國文字變異的遺留

亞當

提要

在傳世文獻中, 神話帝王 “舜” 的字形寫法一直讓人困惑。就今日所 見 “舜” 的字形構件, 學界既沒有確切說明它們的表意功能, 也沒有明 確它們中的哪個構件最能標識 “舜” 字的讀音。《說文解字》雖然保留 了 “舜” 字的古文字形, 但是其中哪些構件是表意的, 哪些構件是表音 的, 同樣是難以緀析。如果不能明晰 “舜” 字的寫法, 就很難如實擬測 它的上古音值, 而且諸多與 “舜” 字存在形音關係的早期文字、文本和 註釋等也將得不到合理的解釋。然而, 在郭店楚簡所見兩種戰國時代的 文本中, 我們首次發現了一種明確無疑的 “舜” 字。這將部分解決上述 的諸多難題, 尤其是 “舜” 字的古音擬測問題, 與之相關的其它系列問 題都將隨之得到解答。本文將就上述部分問題進行考察, 並探討它們在 漢字史和文本傳播中的意義。

Keywords: Shun, Old Chinese, palaeography, guwen, Guodian, Gongyang zhuan

舜，上古音，戰國文字，古文，郭店，公羊傳 